\title{
Imaging the source region of the 2003 San Simeon earthquake within the weak Franciscan subduction complex, central California
}

\author{
Egill Hauksson \\ Division of Geological and Planetary Sciences, California Institute of Technology, Pasadena, California, USA
}

David Oppenheimer and Thomas M. Brocher

U.S. Geological Survey, Menlo Park, California, USA

Received 19 July 2004; revised 14 September 2004; accepted 6 October 2004; published 29 October 2004.

[1] Data collected from the 2003 Mw6.5 San Simeon earthquake sequence in central California and a 1986 seismic refraction experiment demonstrate that the weak Franciscan subduction complex suffered brittle failure in a region without significant velocity contrast across a slip plane. Relocated hypocenters suggest a spatial relationship between the seismicity and the Oceanic fault, although blind faulting on a nearby, unknown fault is an equally plausible alternative. The aftershock volume is sandwiched between the Nacimiento and Oceanic faults and is characterized by rocks of low compressional velocity $(\mathrm{Vp})$ abutted to the east and west by rocks of higher Vp. This volume of inferred Franciscan rocks is embedded within the larger Santa Lucia anticline. Pore fluids, whose presence is implied by elevated $\mathrm{Vp} / \mathrm{Vs}$ values, may locally decrease normal stress and limit the aftershock depth distribution between 3 to $10 \mathrm{~km}$ within the hanging wall. The paucity of aftershocks along the mainshock rupture surface may reflect either the absence of a damage zone or an almost complete stress drop within the low $\mathrm{Vp}$ or weak rock matrix surrounding the mainshock rupture. INDEX TERMS: 7205 Seismology: Continental crust (1242); 7215 Seismology: Earthquake parameters; 7230 Seismology: Seismicity and seismotectonics. Citation: Hauksson, E., D. Oppenheimer, and T. M. Brocher (2004), Imaging the source region of the 2003 San Simeon earthquake within the weak Franciscan subduction complex, central California, Geophys. Res. Lett., 31, L20607, doi:10.1029/2004GL021049.

\section{Introduction}

[2] The 2003 San Simeon mainshock and its aftershocks provided the first extensive suite of travel-time data to image the western side of central Coast Ranges since the installation of modern seismic networks in the area (Figure 1). We determined detailed three-dimensional $\mathrm{Vp}$ and $\mathrm{Vp} / \mathrm{Vs}$ velocity models of the region to investigate the relationship between the earthquake sequence and the Franciscan assemblage. The northwest striking preQuaternary Nacimiento and Holocene Oceanic faults cut across this central portion of the Santa Lucia Range. The mainshock rupture occurred on a fault subparallel to the Oceanic fault and propagated to the southeast for a distance of approximately $30 \mathrm{~km}$ with a maximum up-dip width of 4 to $8 \mathrm{~km}$ [Ji et al., 2004]. The aftershocks lie between the Oceanic and Nacimiento faults, providing new data for crustal structure imaging and synthesizing seismotectonics.

[3] Transpressional strike-slip deformation dominates the tectonics of central California [Zoback et al., 1987]. Dehlinger and Bolt [1987] identified a belt of moderate seismicity exhibiting thrust and strike-slip focal mechanisms along the coast where the 2003 San Simeon sequence was to occur. McLaren and Savage [2001] investigated faulting in the offshore Santa Maria Basin and related strike-slip faults such as the offshore Hosgri fault. They noted that the Santa Lucia Range in the area of the 2003 San Simeon earthquake is undergoing uplifting through reverse faulting.

[4] The San Simeon earthquake represents brittle faulting within the Franciscan complex, which previously was thought to be unlikely because of its relative mechanical weakness [e.g., Page et al., 1998]. They noted that the complex consists of a mélange of strongly sheared argillaceous material embedded with blocks of oceanic crust as well as terrigenous sedimentary rocks. Thus, the Franciscan complex may consist of highly sheared rocks interspersed with more rigid blocks, such that earthquakes can occur almost at random within these shear zones. In this model, pore fluids may play a strong role in localizing shear stress on faults that have previously slipped [e.g., Zhao et al., 1996].

\section{Vp and $V p / V s$ as Proxies for 3D Geology}

[5] We inverted $P$ and $S-P$ travel-time data from 150, mostly Northern California Seismic Network (NCSN), seismic stations to determine three-dimensional (3D) velocity models and infer the subsurface geology responsible for the 2003 San Simeon sequence, applying the inversion approach and computer algorithms (SIMULPS) developed by Thurber [1993], and data analysis detailed by Hauksson [2000]. We analyzed phase data from 5500 events preceding the mainshock and 7000 events of the 2003-2004 San Simeon sequence. The pre-mainshock seismicity provides additional ray coverage for the edges of the model, especially in the coastal region (Figure $\mathrm{S}^{1}{ }^{1}$ ).

[6] We included in the inversion travel-times measured mostly on vertical components from the 1986 San Luis Obispo, California seismic refraction survey [Sharpless and Walter, 1988]. In this experiment, receivers were deployed 


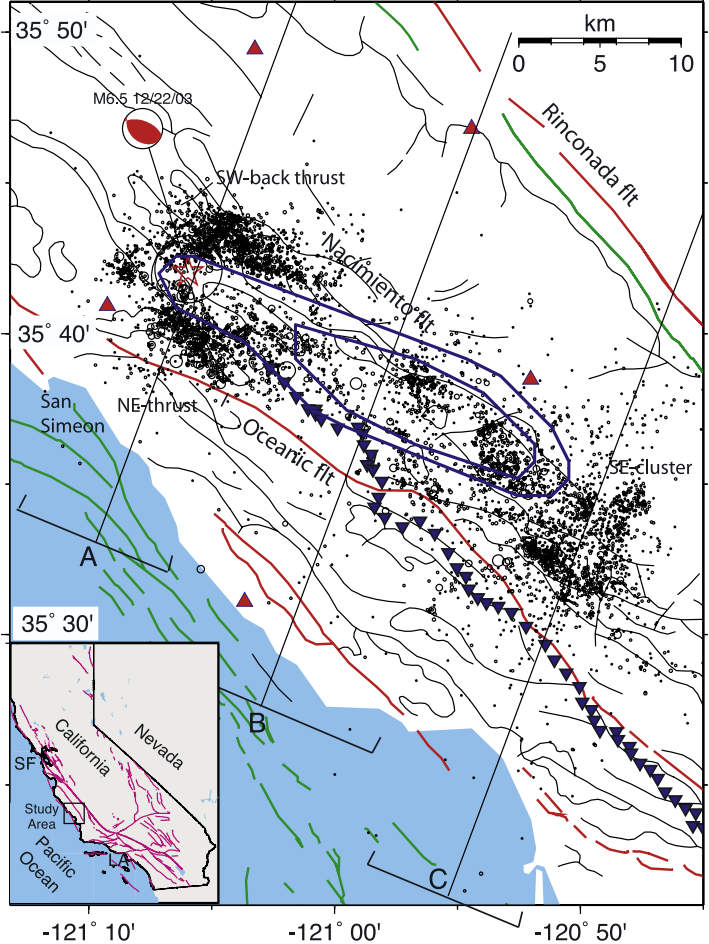

Figure 1. Maps of relocated mainshock-aftershock hypocenters determined with the double difference method, shown as solid circles. The mainshock epicenter is shown as a red star with the moment tensor from Hardebeck et al. [2004], and finite fault model slip contours (blue) from Ji et al. [2004]. Major faults from Jennings [1994] are shown in red (Holocene and Historic) green (Late Quaternary), and black (pre-Quaternary). Seismic stations (red triangles) and the 1986 refraction line (blue inverted triangles) are also shown. SF - San Francisco, LA - Los Angeles.

in a 98-km, northwest-trending profile extending from $13 \mathrm{~km}$ east of San Simeon to the south. Seven out of the ten explosion sources were located away from the refraction line to provide fan geometry, which is more useful for 3D velocity inversions than linear profiles. Five of these explosions were recorded by the NCSN, and those data were included in our velocity inversions.

[7] An initial 1D velocity model was transformed to 3D using a 4-by-4 km horizontal grid that extends from the coastline to the Rinconada fault and that encompasses the aftershock zone (Figure S1). The depths of the grid layers are $0.3,4,6,8,12$, and $16 \mathrm{~km}$ and image the entire aftershock volume. Before the final inversion, the 4-by-4 km grid was interpolated to a 2-by- $2 \mathrm{~km}$ horizontal grid with added depth layers at $2 \mathrm{~km}$ and $10 \mathrm{~km}$ to improve the spatial resolution.

[8] In general, the $\mathrm{Vp}$ model is well resolved across the aftershock zone and adjacent regions. We use the value of the derivative weighted sum (DWS) (Figure S3) at each grid node to determine the ray coverage of the model [Thurber, 1993]. The resolution decreases rapidly in the offshore area, to the southwest, and to the southeast where both the background seismicity and aftershock activity are much lower.

[9] The 3D velocity model images the Franciscan formation in the region of the 2003 San Simeon earthquake sequence (Figure 2). The 3D Vp crustal velocities are low but typical of Franciscan rocks in central California [Walter and Mooney, 1982]. Perspective views of the iso-velocity surfaces of the $\mathrm{Vp}$ model exhibit strong lateral variations from east to west. The major northwest striking faults correlate with abrupt steps in the $\mathrm{Vp} 4.5 \mathrm{~km} / \mathrm{s}$ iso-surface, with the Rinconada and Nacimiento fault zones forming the clearest step from 0 to $2 \mathrm{~km}$ depth. The $6 \mathrm{~km} / \mathrm{s}$ iso-velocity surface is depressed across the whole region and extends to depths of $16 \mathrm{~km}$ between the Nacimiento and Oceanic faults. An extensive depression of the $6.0 \mathrm{~km} / \mathrm{s}$ iso-velocity surface exists $10 \mathrm{~km}$ southeast of the mainshock epicenter and coincides with the zone of large mainshock slip [ $\mathrm{Ji}$ et al., 2004].

[10] Our 1D regional velocity model that best minimized the travel-time data has an average $\mathrm{Vp} / \mathrm{Vs}$ ratio of 1.73 . The $3 \mathrm{D} \mathrm{Vp/Vs} \mathrm{model} \mathrm{is} \mathrm{not} \mathrm{as} \mathrm{well} \mathrm{resolved} \mathrm{as} \mathrm{the} \mathrm{Vp}$ model because the $\mathrm{S}$ picks comprise only $4.5 \%$ of the dataset. Both the $\mathrm{Vp}$ and $\mathrm{Vp} / \mathrm{Vs}$ models image a similar northwesttrending fabric. There is a sharp contrast in $\mathrm{Vp} / \mathrm{Vs}$ across the Rinconada fault, with lower $\mathrm{Vp} / \mathrm{Vs}$ to the east and higher $\mathrm{Vp} / \mathrm{Vs}$ to the west, which is consistent with the granitic and Franciscan rocks, respectively. The mainshock rupture zone coincides with an elevated $\mathrm{Vp} / \mathrm{Vs}$ of $\sim 1.8$ suggesting the presence of a few volume percent of crustal fluids [Nakajima et al., 2001].

\section{Relocated Hypocenters and Faulting}

[11] To obtain the best possible hypocenters for the mainshock and aftershocks, we apply two different methods sequentially. First, to determine robust absolute locations,

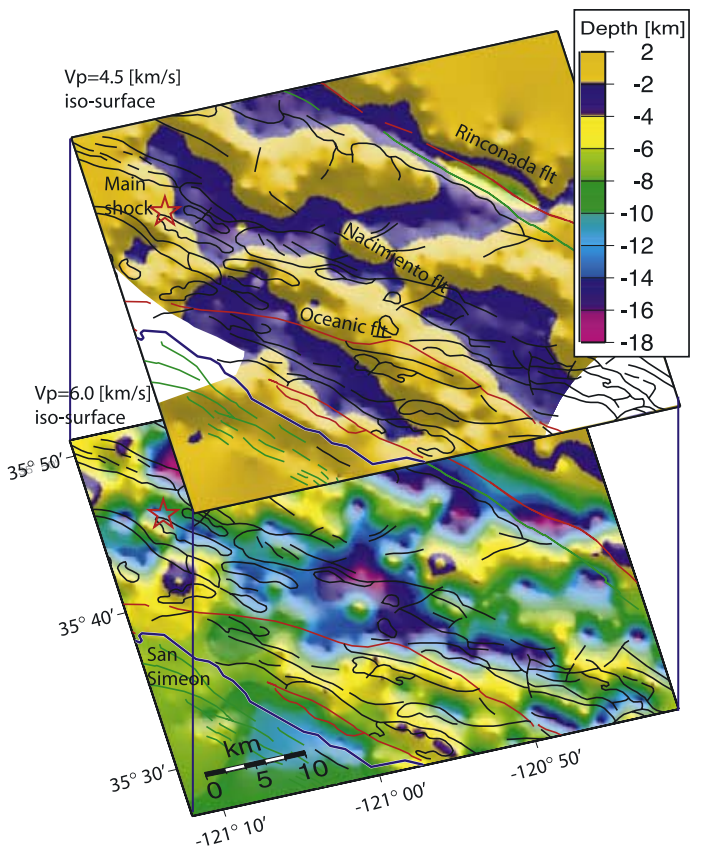

Figure 2. Perspective view of iso-surfaces for $\mathrm{Vp}$ of 4.5 and $6.0 \mathrm{~km} / \mathrm{s}$ of the $3 \mathrm{D} \mathrm{Vp}$ model for the region of the 2003 San Simeon earthquake. The mainshock epicenter is shown as a red star for reference. Major faults as in Figure 1. The coast is indicated by a blue line. Poorly resolved regions of the model are not shown. 

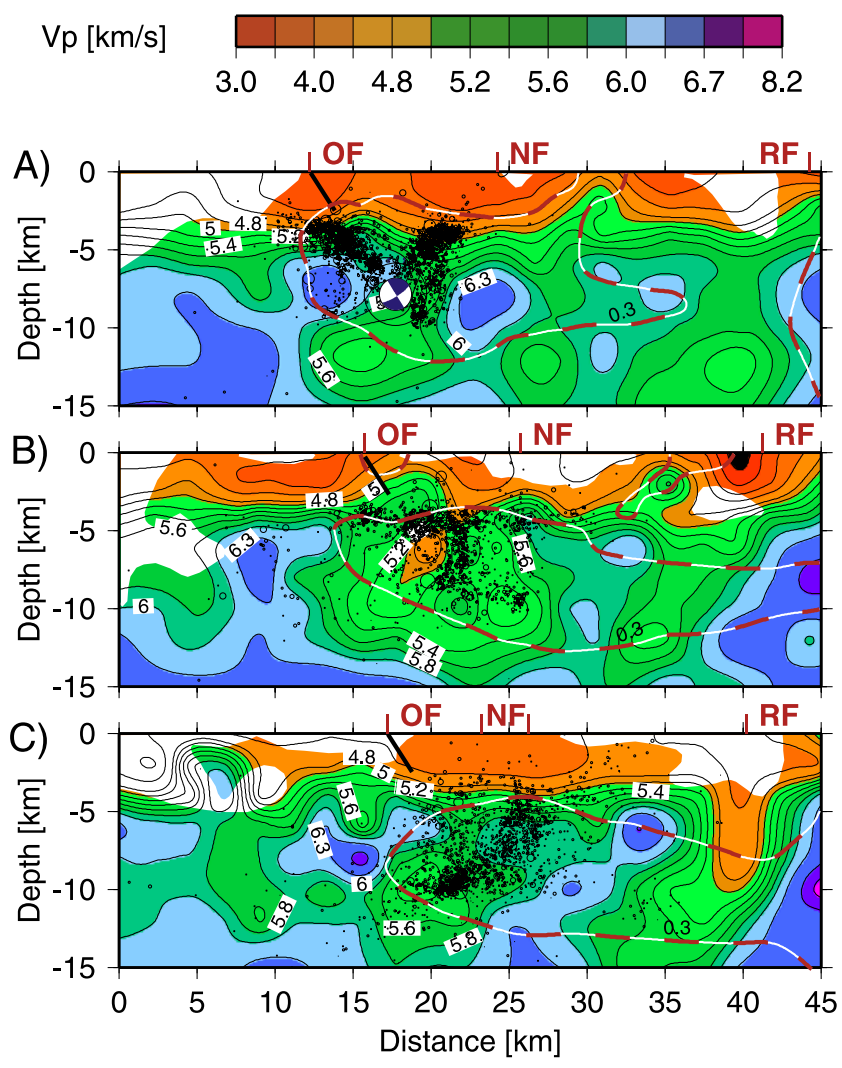

Figure 3. Three depth sections through the Vp model with the relocated aftershocks. The $\mathrm{A}, \mathrm{B}$, and $\mathrm{C}$ cross sections are indicated by lines, and aftershocks that plot within the brackets are included in the cross sections, see Figure 1. The dipping line projects the Oceanic fault into the model with a $58^{\circ}$ dip from the mainshock moment tensor of Hardebeck et al. [2004]. OF, Oceanic fault, NF, Nacimiento fault, and RF, Rinconada fault. In cross section $\mathrm{A}$, the mainshock hypocenter is also plotted as the moment tensor from Hardebeck et al. [2004]. The 0.3 value of the diagonal element of the resolution matrix is plotted as a dashed (red-white) line. Poorly resolved regions of the model with DWS $\leq 100$ are not shown.

we relocate hypocenters using the new 3D $\mathrm{Vp}$ and $\mathrm{Vp} / \mathrm{Vs}$ models and the methods of Thurber [1993]. Second, to improve the relative locations we refine the hypocenters from the 3D velocity models using the double difference algorithm (HypoDD) by Waldhauser and Ellsworth [2000]. The double difference method typically "sharpens" the earthquake distribution, such that earthquakes often align and presumably image active faults (Figure S2). The sharpening is accomplished by including new double difference data, while filtering out double difference data with high residuals and reducing the importance of phase picks not available for adjacent events. In this study, the technique clustered the seismicity by moving the shallowest events a few $\mathrm{km}$ deeper and the deepest events up to a shallower depth by a few $\mathrm{km}$.

[12] We evaluated the absolute location accuracy of the hypocenters by relocating five shots from the 1986 San Luis Obispo refraction experiment recorded by the NCSN
(Figure S1). The two shots located within the model have epicenters within $0.8 \mathrm{~km}$ of their true horizontal location and $1.7 \mathrm{~km}$ of their vertical location, suggesting absolute horizontal and vertical location errors of $\sim 1.0$ and $\sim 2.0 \mathrm{~km}$ near the surface, which is the same location accuracy found by Brocher [2003]. The earthquake hypocenters calculated with the 3D models have average horizontal errors of $1.0 \mathrm{~km}$ and vertical errors of $2.0 \mathrm{~km}$.

[13] Both the 3D models and the double difference approach provided similar hypocenters for the mainshock. The focal depth of the mainshock determined from the $3 \mathrm{D}$ velocity model using a distance cutoff of $50 \mathrm{~km}$ is slightly deeper $(9.6 \pm 1.0 \mathrm{~km})$, whereas the $1 \mathrm{D}$ model with station delays and the double difference method provided focal depth of 8.1 and $7.8 \mathrm{~km} \pm 1.0 \mathrm{~km}$. By excluding stations beyond a certain distance we can weakly control the depth of the mainshock by balancing the influence of up-going and down-going rays. Changing the distance cut-off from $50 \mathrm{~km}$ to $200 \mathrm{~km}$ increased the focal depth of the mainshock by about $2 \mathrm{~km}$ because the Vp model is less accurate outside the dense grid. Similarly, testing several starting depths showed that the mainshock focal depth is only weakly dependent on the starting depth. The shallower depth of $7.8 \mathrm{~km}$ from the double difference algorithm is preferred because it agrees well both with the moment tensor depth [Hardebeck et al., 2004] and the finite source model [Ji et al., 2004].

[14] Relocated mainshock and aftershock hypocenters form a southeast trending distribution between the Oceanic and Nacimiento faults (Figure 1). In map view, clusters of aftershocks bracket the region of high slip in the finite fault model [ $\mathrm{Ji}$ et al., 2004]. A prominent dense aftershock cluster (SE cluster) that is located beyond the southeast end of the mainshock rupture is associated with vertical and steeply, SW-dipping faulting [Hardebeck and Michael, 2004].

[15] The aftershocks that are distributed between both the footwall and the hanging wall occurred within a volume of similar lower $\mathrm{Vp}(5.0-5.8 \mathrm{~km} / \mathrm{s})$ but not along a clearly defined discontinuity in the velocity structure (Figures 3 and S3). The depth distribution of the aftershocks is mostly limited to the depth range of the mainshock slip or 3 to $10 \mathrm{~km}$. The upper limit of $3 \mathrm{~km}$ mostly coincides with the base of the near-surface low Vp sedimentary layer. Cross section (A) through the hypocenter of the mainshock, shows aftershock hypocenters associated with the NE dipping mainshock thrust as well as with a SW dipping back thrust [Hardebeck and Michael, 2004]. The $5 \mathrm{~km} / \mathrm{s}$ Vp contour above the projection of the mainshock rupture extends to a shallower depth than elsewhere, consistent with the uplift produced by the earthquake. Cross section (B) projects through the area of highest coseismic slip and an anomalously low $\mathrm{Vp}$ zone in the depth range of 5 to $9 \mathrm{~km}$ but shows no clear evidence of a NE-dipping zone of a dense cluster of aftershock surrounding the mainshock rupture. Low Vp Franciscan rocks imaged by the inversion appear to be confined to a trough between rocks with higher $\mathrm{Vp}$ to the west and east, suggesting overthrusting of the low $\mathrm{Vp}$ rocks. The third cross section $(\mathrm{C})$ is located just beyond the SE extent of the rupture. The two largest clusters of seismicity on this cross section indicate a possible SW-dipping thrust [Hardebeck and Michael, 
2004]. Similarly, these aftershocks fall within regions of elevated Vp/Vs (Figures S4 and S5).

\section{Discussion and Conclusions}

[16] Major features of our 3D velocity model are similar to those of a model along the PG\&E-1 profile, located approximately $25 \mathrm{~km}$ south of the mainshock [Miller et al., 1992]. Their model exhibits low Vp velocities (5.0 to $5.75 \mathrm{~km} / \mathrm{s}$ ) extending from 4 to $15 \mathrm{~km}$ depth underlain by a steeply east dipping interface. They interpreted this interface as the top of the subducted oceanic crust because of the observed velocities of 6.6 to $7.0 \mathrm{~km} / \mathrm{s}$ in the depth range of 15 to $23 \mathrm{~km}$. They also identified a high $\mathrm{Vp}$ body (6.6 to $6.7 \mathrm{~km} / \mathrm{s}$ ) in the depth range of 8 to 15 and embedded in $5.7 \mathrm{~km} / \mathrm{s}$ material. Our model implies the presence of Franciscan Complex rocks beneath the Santa Lucia Range, which is similar to that of Walter and Mooney [1982] who analyzed seismic refraction data collected in the Diablo Range.

[17] The Vp model shows that Rinconada fault bounds the Santa Lucia Range and the Gabilan Range of the Salinian block to the east. The Salinian block has a higher Vp than the Santa Lucia Range to the west because it consists of mostly granitic rocks near the surface and gneissic rocks at depth [Walter and Mooney, 1982]. Transpression of the region has left the Salinian block largely undeformed but has created blind thrusts and high angle reverse faults in the Franciscan Complex, resulting in 20 to $40 \%$ shortening of the low Vp rocks [Page et al., 1998].

[18] The 2003 San Simeon mainshock may have been caused either by movement on the Oceanic fault or alternatively by movement on an adjacent blind thrust fault. The precise relationship between the mainshock and the Oceanic fault is currently unknown because the dip of the Oceanic fault is poorly constrained and the mainshock did not cause surface rupture [Treiman et al., 2004]. The velocity model, the relocated aftershocks presented here, and the mainshock moment tensor [Hardebeck et al., 2004] can be interpreted in several ways. If the dip of the Oceanic fault is $58^{\circ}$ to the northeast, it would dip subparallel to one of the nodal planes of the mainshock moment tensor and the dipping distribution of aftershocks. In contrast, if the Oceanic fault is vertical or steeply dipping $\left(70^{\circ}\right.$ to $\left.90^{\circ}\right)$, rupture likely occurred on a buried thrust in the region.

[19] The San Simeon aftershock sequence exhibited similar characteristics to other California thrust events although in detail there are some significant differences. The 1983 Coalinga and 1985 Kettleman Hills earthquakes occurred at the sediment-basement interface and had aftershock distributions that were scattered within the hanging wall but that did not outline the mainshock rupture [Stein and Ekstrom, 1992]. They proposed that the broad 1983 Coalinga aftershock zone was the result of high, sustained off-fault stress from the fault tip of the mainshock causing aftershocks to occur on secondary faults. We speculate that the 2003 San Simeon earthquake occurred in a different environment. Our results suggest that the sequence ruptured a heterogeneous zone saturated with pore fluids. Thus, the mainshock released only localized strain associated with folding of the weak Franciscan rocks, and caused scattered clusters of aftershocks both above and below the mainshock rupture surface.

[20] There are similarities between the San Simeon earthquake and the 1999 Chi-Chi, Taiwan, earthquake that started close to the sediment - basement interface, but ruptured through weak sediments with significant seismic moment release $[J i$ et al., 2003]. In this respect the San Simeon earthquake corresponds to the upper half of the Chi-Chi rupture, and it would have been much larger if it had started deep, along the Franciscan - subducted ocean plate interface.

[21] Acknowledgments. The NCSN produced the data that were made available at the Northern California Earthquake Data Center. The figures were made using GMT [Wessel and Smith, 1991]. Supported by USGS/NEHRP Grant 04HQGR0052. Contribution \# 9100, GPS, Caltech, Pasadena.

\section{References}

Brocher, T. H. (2003), Hypocentral accuracy of surficial detonations in northern California, Seismol. Res. Lett., 74, $12-19$.

Dehlinger, P., and B. A. Bolt (1987), Earthquakes and associated tectonics in a part of coastal central California, Bull. Seismol. Soc. Am., 77, 2056-2073.

Hardebeck, J. L., and A. J. Michael (2004), Aftershocks of the 2003 Mw6.5 San Simeon earthquake: Relocations and focal mechanisms (abstract), Seismol. Res. Lett., 74, 294.

Hardebeck, J. L., et al. (2004), Preliminary report on the 22 December 2003, M6.5 San Simeon, California earthquake, Seismol. Res. Lett., 75, $155-172$.

Hauksson, E. (2000), Crustal structure and seismicity distributions adjacent to the Pacific and North America plate boundary in southern California, J. Geophys. Res., 105, 13,875-13,903.

Jennings, C. W. (1994), Fault activity map of California and adjacent areas, map, scale 1:750,000, Calif. Div. of Mines and Geol., Sacramento.

Ji, C., D. V. Helmberger, D. J. Wald, and K.-F. Ma (2003), Slip history and dynamic implications of the 1999 Chi-Chi, Taiwan, earthquake, J. Geophys. Res., 108(B9), 2412, doi:10.1029/2002JB001764.

Ji, C., K. M. Larson, Y. Tan et al. (2004), Slip history of the 2003 San Simeon earthquake constrained by combining 1-Hz GPS, strong motion, and teleseismic data, Geophys. Res. Lett., 31, L17608, doi:10.1029/ 2004GL020448.

McLaren, M. K., and W. U. Savage (2001), Seismicity of south-central Coastal California: October 1987, Bull. Seismol. Soc. Am., 91, 1629-1658. Miller, K. C., J. M. Howie, and S. D. Ruppert (1992), Shortening within underplated ocean crust beneath the central California margin, J. Geophys. Res., 97, 19,961-19,980.

Nakajima, J., T. Matsuzawa, A. Hasegawa, and D. Zhao (2001), Threedimensional structure of $\mathrm{V}_{\mathrm{p}}$ and $\mathrm{V}_{\mathrm{s}}$ and $\mathrm{V}_{\mathrm{p}} / \mathrm{V}_{\mathrm{s}}$ beneath northeastern Japan: Implications for arc magmatism and fluids, J. Geophys. Res., 106, 21,843-21,857.

Page, B. M., G. A. Thompson, and R. G. Coleman (1998), OVERVIEW: Late Cenozoic tectonics of the central and southern Coast Ranges of California, GSA Bull., 110, 846-876.

Sharpless, S. W., and A. W. Walter (1988), Data report for the 1986 San Luis Obispo, California seismic refraction survey, U.S. Geol. Surv. Open File Rep., 88-35, 8 pp.

Stein, R. S., and G. Ekstrom (1992), Seismicity and geometry of a $110 \mathrm{~km}$ long blind thrust fault: 2. Synthesis of the 1982-1985 California earthquake sequence, J. Geophys. Res., 97, 4865-4883.

Thurber, C. H. (1993), Local Earthquake Tomography: Velocities and $V p / V_{S}$ - Theory, Chapman and Hall, New York.

Treiman, J. A., et al. (2004), Surface effects of the 22 December 2003 Mw 6.5 San Simeon earthquake (abstract), Seismol. Res. Lett., 74, 264.

Waldhauser, F., and W. L. Ellsworth (2000), A double-difference earthquake location algorithm: Method and application to the Northern Hayward fault, California, Bull. Seismol. Soc. Am., 90, 1353-1368.

Walter, A. W., and W. D. Mooney (1982), Crustal structure of the Diablo and Gabilan Ranges, Central California: A reinterpretation of existing data, Bull. Seismol. Soc. Am., 72, 1567-1590.

Wessel, P., and W. H. F. Smith (1991), Free software helps map and display data, Eos Trans. $A G U, 72,441,445-446$.

Zhao, D., H. Kanamori, H. Negishi, and D. Wiens (1996), Tomography of the source area of the 1995 Kobe earthquake: Evidence for fluids at the hypocenter?, Science, 274, 1891-1894.

Zoback, M. D., et al. (1987), New evidence on the state of stress of the San Andreas fault system, Science, 238, 1105-1111.

T. M. Brocher and D. Oppenheimer, U.S. Geological Survey, Menlo Park, CA 94025, USA.

E. Hauksson, Division of Geological and Planetary Sciences, California Institute of Technology, Pasadena, CA 91125, USA. (hauksson@gps. caltech.edu) 